\title{
Mediatization and Commodification of Religion: A Study of Media Sociology in Sharia Housing Ads
}

\author{
Addin Kurnia Putri ${ }^{1}$, Yuyun Sunesti ${ }^{2}$ \\ \{addinkurniaputri@staff.uns.ac.id ${ }^{1}$,yuyun_sunesti@staff.uns.ac.id² \\ Universitas Sebelas Maret ${ }^{1}$, Universitas Sebelas Maret ${ }^{2}$
}

\begin{abstract}
Media Sociology was concerned with social change and changing interactions that have contributed to media studies. Given the focused on the various relationships between mediated communication and social relations in society. Since the Covid-19 pandemic, reality has changed massively to digital transformation, including in the marketing of commodity products. Now, the media had an important role in constructing the cultural and socio-religious environment. This study aimed to analyze the mediatization and commodification of religion in sharia housing advertisements. This study reviewed the mediatization in constructing social change concerning the current trend of the Muslim community. This study used the virtual ethnography method to analyze religious symbols as culture in sharia housing advertisements. The results of the study concluded that: (1) theoretically, mediatization was an alternative to media sociology studies that focused on the media space and religious practice. Mediatization of religion was a new way to live religious experiences in daily life, especially related to housing following Islamic law; (2) Islamic housing advertisements have commodified religious values through the religious symbols used. This has made it possible to bring religion closer to popular media culture so that it could reach audiences widely; (3) The commodification of religion had the opportunity to influence Muslim consumption behavior. Sharia housing advertisements created a need for Islamic residential facilities and a new lifestyle through a religious approach. In the end, the commodification of religion in Sharia housing advertisements also influenced the dominant culture of religious consumption and leads to exclusivity. The meeting between religiosity and commercial was increasing through the emergence of new technological media. It was not related to religious practice, religiosity, and sacred, but instead followed the logic of the market economy to get as much profit as possible by creating new markets. Mediatization has become the daily life of the community, as well as the Muslim community so that it couldn't be separated from even religious institutions in society. The media has represented a shift in needs from inclusive housing to exclusive housing that created an enclave society, a homogeneous society with the same religious identity. The media has framed and presented religion in a commodified media space and perhaps without prioritizing the sacredness of religion.
\end{abstract}

Keywords: Commodification; Mediatization; Media Sociology; Sharia Housing 



\section{Introduction}

The impact of the Covid-19 pandemic has been detrimental in all sectors, including the economic sector. However, this pandemic has also had a positive effect on accelerating the digital transformation of the economic sector, accelerating the development of the Islamic economy in Indonesia in particular. According to the Inventure-Alvara survey (2021), the impact of the Covid-19 pandemic is as many as 58\% of people have chosen financial institutions that comply with Sharia provisions. Factors causing these changes include external factors, namely Financial Technology, millennial encouragement, and the acceleration of the pandemic (Maesaroh 2021).

Millennial society has become one of the strong driving factors for digital transformation due to the integration of this generation's life in digital-based transactions. Millennials have habits that are close to digital technology in everyday life. Apart from being close to the digital world, the millennial generation is also familiar with the trend of emigration which leads to the consumption of sharia-based products. These products include sharia hijab, sharia banking, sharia hotels, halal food, including sharia housing, which is termed a halal lifestyle concept (Putri and Sunesti 2021).

We can see some examples of sharia housing branding here, sharia islamic cimuncang, sharia property developer, jamila sharia property. All of them construct religious symbols.

The trend of Islamic economics has also been strengthened by the phenomenon of the halal lifestyle which is growing rapidly in recent times. This is evidenced by Indonesia being ranked fourth in the world on the Global Islamic Economy Indicator (GIEI) score. Indonesia got a score of 91.2 in 2020. Indonesia's position is below Malaysia at 290,2, Saudi Arabia at 155.1, and the United Arab Emirates at 133. Other countries that are included in the top 10 list are Jordan and Bahrain with scores around 80 points, Kuwait and Pakistan around 70 points, then Iran and Qatar around 60 points (Lidwina 2020).

This halal lifestyle is caused by the widespread commodification of religion as a popular product. Possamai (2005) argues that the religion that happened this time was very different from the religion of the previous times. With this sentence, Possamai explained that there has been a transformation in carrying out religious practices today. Previous religious teachings showed that religious rituals were sacred and carried out by the standard, religion was part of privacy that did not deserve to be discussed and shown in public spaces (Setiansah 2015).

Due to the spread of information technology in this digital era, religious activities have undergone various changes. Religious activities have become very flexible so that they can be done anytime, anywhere, and can be adapted to the needs. To get information related to religion, it is enough to access it using the available media. As explained in the study of Putri and Sunesti (2021) that the phenomenon of sharia housing in the media is increasingly widespread in recent years. Sharia housing is a residential concept that incorporates religious elements into its practice. This can be seen from the data that appeared on Google Trends for the 2015-2020 period. This study analyzes how the mediatization and commodification of religion in Sharia housing advertisements. In addition, it also examines the extent to which mediatization constructs social change to the image trend of the needs of the Muslim community currently.

Mediatization is a process of how the media contribute to shaping social change in the modern era. Mediatization is closely related to the influence of the media with a wide audience and how the audience is very dependent on the media (Lundby 2012). Mediatization is related to socio-cultural changes in society. Therefore mediatization is a social process of society becoming very saturated and imploded by the media. So that the media and society 
cannot be separated (Aulia 2017). Mediatization is a process of social change, to some extent incorporating other social or cultural fields into the logic of the media. In the case of religion, the media - as a channel, language, and environment - facilitate changes in the number, content, and direction of religious messages in society, at the same time as they alter religious representations and challenges and replace institutionalized religious authority (Hjarvard 2008).

Mediatization supports publicity for the widespread commodification of religion. According to Fealy and Sally, the widespread commodification of Islam is a suggestion that the presence of Islam in the public sphere be taken for granted. Furthermore, consumption of halal products, sharia housing, is also related to social identity. The massive flow of globalization has an impact on the occurrence of destabilized identity when religion becomes one of the alternatives to create a new identity. This means that consumption of products such as sharia housing in Bourgeois terminology is used as symbolic capital to strengthen identity and maintain the position of individual Muslims in their social class, the Muslim middle class. For Fealy \& White (2012), consumption of Islamic products often shows a high social status in society. From the explanation above, it can be seen that several studies have been conducted previously related to mediatization and commodification in religion (Aulia 2017; Fakhruroji 2014; Jasmine 2021; Khumairoh 2017; Setya, Gelgel, and Pradipta 2020). However, from the many previous studies, no one has analyzed related to Sharia housing. Meanwhile, commodification is the subordination of the private and public spheres to the logic of capitalism. In this way, they are no longer treated as goods with intrinsic value but as commodities (Maloney 2020).

This study aims to explore the construction and meaning of religion in sharia housing advertisements as a mediated religion, the commodification of religion and the internalization of media logic carried out by sharia housing developers as producers as well as the implications of mediating religion at the level of daily religious practice and how the Covid pandemic is. 19 as one of the factors driving the mediatization of religion which is increasingly massive in sharia-based residential advertisements. To achieve these goals, this study uses a qualitative approach with a critical paradigm by using the method of discourse analysis as well as being applied to texts which are Islamic housing advertising content but remain within the framework of critical discourse, without intending to generalize on reality with similar phenomena.

\section{Findings, Analysis/Discussion}

\subsection{Mediatization of Religion through Sharia housing ads}

So, what is Islamic housing? Sharia housing is a halal product that claims to use shariabased transactions. In addition, their products also offer a halal lifestyle in a sharia environment. The concept of religious values entered the residential property business, estimated to have emerged around 1995. The potential of the Muslim market (especially the Muslim middle class) is quite large, encouraging developers to control land and commodify space by selling religious symbols. 


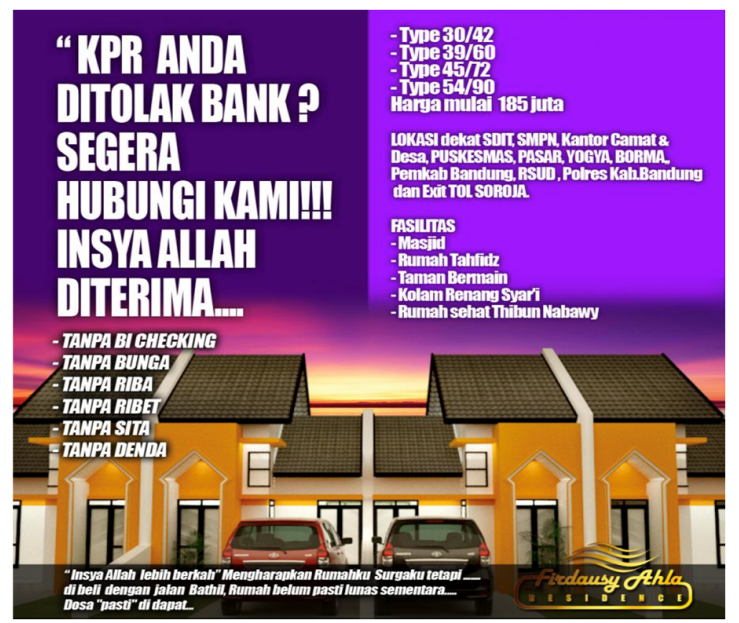

Fig. 1. Islamic housing ads with religious symbols Source: https://www.homesyariah.com/

The figure above shows an example of an Islamic housing advertisement. In figure 1, we can see how Islamic housing advertisements are produced in the media. In these advertisements, religious symbols appear such as language 'tanpa riba' (without usury), 'berkah' (blessings), 'surga' (heaven), 'bathil' (falsehood), 'dosa' (sin), and 'Insya Allah' (God willing). In addition, the advertisement also shows facilities with religious concepts offered, such as a mosque, a house for Tahfiz Qur'an, a sharia swimming pool, a Thibun Nabawy's healthy house. This kind of advertising narrative appears a lot in social media. The Covid-19 pandemic has also caused Islamic housing advertisements to be increasingly promoted in digital media. They use Islamic concept to attract Muslim consumers.

Media is not only a channel but also how social/political/economic forces have adapted to the media, then use it for their interests. The phenomenon of the practice of mediatization of religion is a form of relationship between religion and the media which indicates the increasingly strong dominance of media logic in Islamic housing advertising as a fantastic place to live based on religious values that lead to Muslim piety.

Shoemaker and Reese (1996) argue that along with the role of the media as a profitmaking enterprise, the media make powerful products to generate profits. Therefore, mass media organizations are often described as similar to other business organizations, which are always developing markets for their products. Media routines at one time are more oriented to one pole but at other times to the other pole as well, depending on the needs of the media itself. News writing routines with an inverted pyramid pattern, for example, are more oriented towards readers and media organizations, namely producers/owners or media managers, except for the news sources. New media (New Media) in the public sphere, especially social media, not only transforms but also changes the subject. In contrast to the old media (Old Media), where the source of information is centered and single. Owners of capital have a significant role in the circulation of information. New media encourages each individual to be both subject and object (prosumer) in making and spreading the news. Here, the information that appears is not only a medium by the media (just a means of delivering), but also becomes part of the modifier itself. 
This mediatization allows the growth of new knowledge that can be accessed and creates democratization by the Indonesian public amid the harmonization of previous religious organizations. However, on the other hand, the emergence of religious authorities through mediatization creates disruptions such as the emergence of various changes that change the old order with the presence of innovations in various fields. Ironically, in this context, it has a destructive power that was previously difficult to anticipate. Islamic housing advertisements can encourage the emergence of enclaves of identity, ideology, and religious exclusivity on social media.

The concept of mediatization refers to the opinion of Stig Hjarvard (2013), which defines it as a long-term process), in which social and cultural institutions and forms of communication change part of the consequences of the growth of the media itself. Regarding the mediatization of religion, Hjavard ( 2013) divides it into three categories: First, the media is the main source of information on religious issues and becomes a platform to express and then carry out the process of circulating individual beliefs. Second, information, as well as the expression of religious experiences, are shaped according to the will of the genre and desires of the media. Third, the media take over social and cultural functions that were previously institutionalized through religions to provide a space for spiritual guidance, moral orientation, and a feeling of belonging and community togetherness.

\subsection{Islamic Housing Advertising as a Commodification of Religion}

This study analyzes the practice of commodification as a continuation of the practice of mediatization of religion. Based on the exploration carried out, several conclusions were obtained that, first, the adoption of media logic by the developers of Islamic housing, especially in the context of how to get the audience interested in their commodity products. second, the institutionalization of sharia housing advertisements as a step to internalize the logic of the media leading to the banalization of religion as a religious practice, and third, the dominance of media logic in sharia housing advertisements has led to the commercialization and commodification of religion. Commercialization is characterized by not only religious but also economic importance. Meanwhile, the practice of commodification is indicated by the commodification of content through the sale of content using religion with profit compensation for Sharia housing developers. the commodification of audiences is characterized by the transformation of Muslim piety to a Muslim middle-class consumer audience through the use of a customer database. Finally, the commodification of the process is marked by efforts to expand services through websites, streaming technology, and social networks which are carried out to lead the public to buy sharia housing products that are offered.

Making advertisements through the internet is an option for many sellers to offer their products. This method is also taken by Islamic housing developers. Through the internet media, messages about products that they claim to be Islamic products are made, circulated, and described convincingly to attract as many buyers as possible. (Sunesti and Putri 2020). As explained in the study that in marketing Islamic housing, developers attract the attention of potential consumers with three main offerings, namely payments with non-usury financing models, sharia environments, and sharia communities. These three things are the main focus of Islamic housing developers and marketers that they are trying to offer to their targeted consumers (Sunesti, Putri, and Anwar 2021). Mass media as a business aims to get the maximum profit. Capitalists take into account the economic aspect rather than paying attention to the socio-cultural aspects of their audience (society). It is in this aspect that Theodore 
Adorno and Mark Horkheimer (Bungin 2001), argue that industrial culture is a deceptive medium.

\section{Conclusion}

This article concludes that the mediatization of religion is one of the sociological studies of media that focuses on the media space and religious practice. Mediatization of religion is a new way of living religious experiences in everyday life, in the context of this study it is related to housing following Islamic law. Sharia housing advertisements have turned religious values or symbols into commodities. The commodification of religion makes it possible to bring religious discourse closer to popular media culture so that it can reach a wider audience, especially the Muslim middle class. The commodification of religion has the opportunity to influence the consumption behavior of Muslims. sharia housing advertisements create a need for Islamic residential facilities and a new lifestyle through a religious approach. In the end, the commodification of religion in sharia housing advertisements also influences the dominant culture of religious consumption and leads to exclusivity.

\section{References}

[1] Aulia, Nisa Nur. 2017. "Islam Dan Mediatisasi Agama." Communicatus Jurnal Ilmu Komunikasi 1(1).

[2] Bungin, Burhan. 2001. Imaji Media Massa Konstruksi Dan Realitas Sosial: Iklan Televisi Dalam Masyarakat Kapitalistik. Yogyakarta: Jendela.

[3] Fakhruroji, Moch. 2014. "Agama Dalam Pesan Pendek: Mediatisasi Dan Komodifikasi Dalam SMS Tauhiid.” Universitas Gadjah Mada.

[4] Fealy, Greg, and Sally White. 2012. Expressing Islam: Religious Life and Politics in Indonesia. Singapore: ISEAS- Institute of Southeast Asian Studies.

[5] Hjarvard, S. 2008. "The Mediatization of Religion: A Theory of the Media as Agents of Religious Change." Northern Lights 6:9-26.

[6] Hjarvard, Stig. 2013. The Mediatization of Culture and Society. Routledge.

[7] Jasmine, Asyifa Nadia. 2021. "Komodifikasi Agama Di Ruang Media Internet: Pengaruh Iklan Online Di Kalangan Muslim.” Universitas Gadjah Mada.

[8] Khumairoh, Izmy. 2017. "Ayo Menikah (Muda)! : Mediatisasi Ajaran Islam Di Media Sosial." UMBARA : Indonesian Journal of Anthropology 2(1):10-23.

[9] Lidwina, Andrea. 2020. "Ekonomi Syariah Indonesia Peringkat Keempat Dunia Pada 2020." Retrieved (https://databoks.katadata.co.id/datapublish/2020/11/18/ekonomisyariah-indonesia-peringkat-keempat-dunia-pada-2020\#).

[10] Lundby, K. 2012. Mediatization of Communication. Germany. Leck: CPI Books $\mathrm{GmbH}$.

[11] Maesaroh. 2021. "Tren Hijrah Ke Ekonomi Syariah Semakin Bersemi Selama Pandemi." Retrieved (https://katadata.co.id/maesaroh/finansial/610115ace8d3f/trenhijrah-ke-ekonomi-syariah-semakin-bersemi-selama-pandemi).

[12] Maloney, Lauren. 2020."The Commodification of Human Beings". nulawreview.org.

[13] Possamai, A. 2005. Religion and Populer Culture, A Hyper-Real Testement. Brussels: P.I.E.

[14] Putri, Addin Kurnia, and Yuyun Sunesti. 2021. "Sharia Branding in Housing Context: 
A Study of Halal Lifestyle Representation.” Jurnal Sosiologi Walisongo 5(1):77-92.

[15] Setiansah, M. 2015. "Smartphonisasi Agama: Transformasi Perilaku Beragama Perempuan Urban Di Era Digital.” Jurnal Komunikasi 10(1).

[16] Setya, Asla Eva, Ni Made Ras Amanda Gelgel, and Ade Devia Pradipta. 2020. "Commodification Of Islamic Values In The Ads Of 'Hijab Fresh' Body Lotion." INJECT (Interdisciplinary Journal of Communication) 5(1):73-96.

[17] Shoemaker, Pamela J., and Stephen D. Reese. 1996. Mediating The Message: Theories of Influences on Mass Media Content, Second Edition. USA: Longman Publisher.

[18] Sunesti, Yuyun, and Addin Kurnia Putri. 2020. "Expressing Piety Through Property Ads: Sharia Housing and Islamic Identity Formation.” in Advances in Social Science, Education and Humanities Research. Atlantis Press.

[19] Sunesti, Yuyun, Addin Kurnia Putri, and Mokhamad Z. Anwar. 2021. "Sharia Housing, Sustainable Communities and Civic Pluralism in Surakarta." in IOP Conf. Series: Earth and Environmental Science. IOP Publishing. 